\title{
CHEMOSPHERE
}

\section{Microbial population of spruce soil in Tatachia mountain of Taiwan}

\author{
Shang-Shyng Yang *, Hsiao-Yun Fan, Chiun-Kai Yang, I-Chien Lin \\ Department of Agricultural Chemistry, National Taiwan University, Taipei 10617, Taiwan, ROC
}

\begin{abstract}
To investigate the role of microorganisms in the ecology and the nutrient transformation of forest soil, soil property, microbial population, biomass and organic acid content of Spruce soil in Tatachia mountain were determined during January 1997 to November 1999. Soil temperatures were between 5.5 and $15.6{ }^{\circ} \mathrm{C}$ and soil $\mathrm{pH}$ ranged from 3.6 to 5.0. Total organic carbon and nitrogen contents ranged from $5.83 \%$ to $34.35 \%$ and from $0.90 \%$ to $3.19 \%$, respectively. C/N ratio was between 7.07 and 18.24. Each gram of dry soil contained microbial biomass carbon 308-870 $\mu \mathrm{g}$, microbial biomass nitrogen 107-240 $\mu \mathrm{g}$, malic acid 74-211 $\mathrm{nM}$ and succinic acid 32-175 $\mathrm{nM}$. In addition, each gram of dry organic layer contained microbial biomass carbon 216-653 $\mu \mathrm{g}$, microbial biomass nitrogen 10.3-33.8 $\mu \mathrm{g}$, formic acid 256-421 nM, acetic acid 301-435 nM, malic acid 795-1027 nM and succinic acid 204-670 nM. About 45.5-90.9\% of topsoil samples had higher microbial population than those of subsoil especially in actinomycetes, cellulolytic and phosphate-solubilizing microorganisms. Although rhizosphere of Spruce had higher total organic carbon and total nitrogen content than non-rhizosphere and dwarf bamboo areas, the microbial population had no significant difference among them.
\end{abstract}

(C) 2003 Elsevier Ltd. All rights reserved.

Keywords: Cellulolytic microbes; Forest soil; Microbial biomass carbon and nitrogen; Nitrogen-fixing microbes; Organic acid; Phosphate-solubilizing microbes

\section{Introduction}

Forest soil microorganisms and fauna decompose organic materials, and thus they strongly influence the nutrient cycling of ecosystem. The numbers and species of microbes in soil vary directly with environmental conditions, nutrient availability, soil texture, and type of vegetation cover (Atlas and Bartha, 1998). Fields cropped continuously to oats contain more fungi, actinomycetes are greater in grassland and pasture soils than in cultivated land, and bacteria in grassland are greater than in arable land (Alexander, 1977).

\footnotetext{
${ }^{*}$ Corresponding author. Tel.: +886-2-2362-1519; fax: +8862-2367-9827.

E-mail address: ssyang@ccms.ntu.edu.tw (S.-S. Yang).
}

In Taiwan, the microbial distributions of soils have only been determined in acidic soil of Yang-ming-san, inorganic acidic soil, upland soil, alkaline soil of Tainan and power plant areas (Chu, 1933; Yang et al., 1998a,b, 1999; Yang and Yang, 2001). There are few data in the microbial population of forest soil (Yang et al., 1998a; Imberger and Chiu, 2001). Tatachia mountain is located in the central part of Taiwan and has been designated as a National Park. There are three major vegetations, Spruce, Hemlock and grass, in this temperate area. It is a typical high altitude ecosystem protected area in Taiwan. For the long-term ecological research in Taiwan, the microbial populations, biomass and organic acid content of Spruce soil during January 1997 to November 1999 were investigated. The effect of season and depth on microbial population and biomass are also studied in this article. 


\section{Materials and methods}

\subsection{Sampling location}

The study was conducted at Tatachia, in the saddle of Jade Mountain, central Taiwan (120 52' E, $23^{\circ} 28^{\prime}$ $\mathrm{N})$. Tatachia has an elevation from 1800 to $3952 \mathrm{~m}$. Some environmental conditions and properties of tested soils are listed in Table 1. The area has been selected as a representative long-term ecological study site of subalpine forest ecosystems in Taiwan. The study area geologically consists of metamorphosed sedimentary rock (Miocene epoch) comprising sandstone and shale. The coniferous forest is dominated by spruce (Picea morrisonicola). Less dominant species include Taiwan false cypress (Chamaecyparis formosensis), Armand's pine (Pinus armandi), Chinese hemlock (Tsuga chinensis), dwarf bamboo (Yushania niitakayamensis), and alpine silver grass (Miscanthus transmorrisonensis).

\subsection{Culture media and conditions}

Bacteria were counted at $25{ }^{\circ} \mathrm{C}$ after 5 days incubation on nutrient agar containing $\left(\mathrm{g}^{-1}\right)$ beef extract 3.0, peptone 5.0, and agar 15.0 at $\mathrm{pH} 6.8 \pm 0.1$. Actinomycetes were cultivated at $25{ }^{\circ} \mathrm{C}$ for 7 days on glycerolyeast extract medium comprised of $\left(\mathrm{gl}^{-1}\right)$ glycerol 5.0, yeast extract 2.0, $\mathrm{K}_{2} \mathrm{HPO}_{4}$ 1.0, and agar 15.0 at $\mathrm{pH}$ $7.0 \pm 0.1$. Streptomycin and cycloheximide were added to inhibit the growth of bacteria and fungi at a final concentration of $10 \mu \mathrm{g} \mathrm{cm}^{-3}$ (Yang et al., 1999). Fungi were grown at $25^{\circ} \mathrm{C}$ for 5 days on Rose bengal medium containing $\left(\mathrm{gl}^{-1}\right)$ glucose 10.0 , peptone 5.0, $\mathrm{K}_{2} \mathrm{HPO}_{4}$ 1.0, $\mathrm{MgSO}_{4} \cdot 7 \mathrm{H}_{2} \mathrm{O} 0.5$, Rose bengal 0.033 and agar 15.0 at $\mathrm{pH} 6.8 \pm 0.1$. Cellulolytic microbes were counted at $25^{\circ} \mathrm{C}$ after 7 days incubation on Mandels-Reese medium with carboxymethylcellulose (Sigma) as the sole carbon source and sprayed with Congo red to show clear zone around the colonies. Phosphate-solubilizing microbes were measured at $25{ }^{\circ} \mathrm{C}$ after 5 days on rock phosphate medium and had clear zone around the colonies. Nitrogen-fixing microbes were characterized at $25^{\circ} \mathrm{C}$ after 7 days incubation on nitrogen-free mannitol medium (Yang et al., 1998a). All the experiments were carried out in triplicate.

\subsection{Seasonal variation of microbial ecology}

Temperatures are high in summer and low in winter. Soil samples were collected at different seasons from January 1997 to November 1999. Organic matter content is high in the organic layer and the value is low in the subsoil. Cellulolytic, phosphate-solubilizing and nitrogen-fixing microbes are very important in grassland and forest soil for the elemental cycle and the nutritional supplement. Bacteria, actinomycetes, fungi, cellulolytic, phosphate-solubilizing and nitrogen-fixing microbes were counted in both the topsoil (0-20 cm depth) and the subsoil (21-40 cm depth). Microbes in the organic layer were also analyzed in December 1998, March and April 1999 for comparison.

\subsection{Effect of soil profile on microbial populations}

Soil profiles were taken from the spruce zone and classified into horizons according to the international soil classification system (Soil Survey Staff, 1994). Soil samples were collected from each horizon and transported to the laboratory from the top of soil to $100 \mathrm{~cm}$ depth in September 1998. Microbial populations at each

Table 1

Environmental conditions and properties of tested Tatachia forest soils

\begin{tabular}{llll}
\hline Properties & Organic layer & Topsoil $(0-20 \mathrm{~cm})$ & Subsoil $(21-40 \mathrm{~cm})$ \\
\hline Altitude $(\mathrm{m})$ & 2500 & 2500 & 2500 \\
Annual precipitation $(\mathrm{mm})$ & $2800-3000$ & $2800-3000$ & $2800-3000$ \\
Soil texture & - & Sandy loam & Sandy loam \\
Vegetation & Picea, morrisonicola, spruce, dwarf bamboo & Grey to blackish grey & Grey to yellowish grey \\
Color & Blackish brown & & \\
Temperature $\left({ }^{\circ} \mathrm{C}\right)$ & & & \\
$\quad$ Air & $0.0-17.9$ & $5.8-15.3$ & $6.0-14.9$ \\
Soil & $5.5-15.6$ & & $3.83-4.99$ \\
Light intensity $(\mathrm{lx})$ & $577-2667$ & $3.77-4.83$ & \\
pH & $3.58-4.19$ & $33.9-55.8$ & $29.0-45.9$ \\
Moisture content $(\%)$ & & $46.7-191.9$ & $36.5-141.8$ \\
$\quad$ Wet weight basis & $61.0-73.7$ & $155.0-376.2$ & $97.5-143.5$ \\
$\quad$ Dry weight basis & $89.7-270.5$ & $11.09-24.51$ & $5.83-11.20$ \\
Water holding capacity $(\%)$ & $389.7-498.3$ & $1.06-2.87$ & $0.90-1.90$ \\
Total organic carbon $(\%)$ & $23.66-34.35$ & $8.22-14.31$ & $7.07-9.31$ \\
Total nitrogen $(\%)$ & $1.26-3.19$ & & \\
C/N ratio & $7.42-18.24$ & & \\
\hline
\end{tabular}


horizon were measured for studying the effect of depth on microbial distribution.

\subsection{Total nitrogen}

Soil samples were air-dried and digested with concentrated $\mathrm{H}_{2} \mathrm{SO}_{4}$. Total nitrogen was determined with a modified Kjeldahl method (Yang et al., 1991).

\subsection{Total organic carbon}

Soil sample $1.0 \mathrm{~g}, 1 \mathrm{~N} \mathrm{~K}_{2} \mathrm{Cr}_{2} \mathrm{O}_{7} 10 \mathrm{~cm}^{3}$ and concentrated $\mathrm{H}_{2} \mathrm{SO}_{4} 20 \mathrm{~cm}^{3}$ were mixed thoroughly, left to stand for $30 \mathrm{~min}$, after which distilled water $200 \mathrm{~cm}^{3}$ and $85 \% \mathrm{H}_{3} \mathrm{BO}_{3} 10 \mathrm{~cm}^{3}$ were added. After cooling, diphenylamine $1 \mathrm{~cm}^{3}$ was added as indicator and the reaction mixture was titrated with $0.5 \mathrm{~N}$ ferrous (II) ammonium sulfate (Nelson and Sommers, 1982).

\subsection{Microbial biomass carbon}

Microbial biomass carbon was determined by the fumigation-extraction method (Vance et al., 1987). Soil sample ( $25 \mathrm{~g})$ at $40 \%$ water-holding capacity and boiled chloroform (ethanol removal) $\left(50 \mathrm{~cm}^{3}\right)$ were put in a desiccators for 20-24 h. After fumigation, $0.5 \mathrm{M} \mathrm{K}_{2} \mathrm{SO}_{4}$ $100 \mathrm{~cm}^{3}$ was added, shaken at $250 \mathrm{rpm}$ for $30 \mathrm{~min}$, and filtered through Whatman No. 42 filter paper. Soil extract $8.0 \mathrm{~cm}^{3}$ and $0.066 \mathrm{M} \mathrm{K}_{2} \mathrm{Cr}_{2} \mathrm{O}_{7} 2.0 \mathrm{~cm}^{3}, \mathrm{HgO} 70$ mg, conc. $\mathrm{H}_{2} \mathrm{SO}_{4} 10.0 \mathrm{~cm}^{3}$ and $85 \% \mathrm{H}_{3} \mathrm{PO}_{4} 5.0 \mathrm{~cm}^{3}$ were mixed thoroughly. The mixture was refluxed for $30 \mathrm{~min}$. After cooling, distilled water $20 \mathrm{~cm}^{3}$ was added from the top to recover the reaction mixture, $0.025 \mathrm{M} 1,1$-phenanthroline-ferrous sulfate mixture $0.1 \mathrm{~cm}^{3}$ was added as the indicator. The reaction mixture was back-titrated with $0.033 \mathrm{M}$ ferrous (II) ammonium sulfate. Microbial biomass carbon was calculated as the difference of carbon content between non-fumigated and fumigated soil extracts.

\subsection{Microbial biomass nitrogen}

Microbial biomass nitrogen was measured by a fumigation-extraction method (Raghubanshi, 1991). The soil fumigation extract $5 \mathrm{~cm}^{3}, \mathrm{Na}_{2} \mathrm{~S}_{2} \mathrm{O}_{3} 0.5 \mathrm{~g}$ and salicylic acid $0.5 \mathrm{~g}$ were dried at $60{ }^{\circ} \mathrm{C}$, and the nitrogen content of the dry sample was determined by a modified Kjeldahl method (Yang et al., 1991) and microbial biomass nitrogen was calculated by the difference of nitrogen content between non-fumigated and fumigated soil extracts.

\subsection{Organic acid determination}

About $20 \mathrm{~g}$ soil and $20 \mathrm{~cm}^{3}$ deionized water were mixed thoroughly at $100 \mathrm{rpm}$ on a shaker for $1 \mathrm{~h}$, and filtered through Whatman No. 42 filter paper. After filtration with $0.46 \mu \mathrm{m}$ Millipore filter, organic acid was determined with a Shimadzu LC-9A high performance liquid chromatograph (Shimadzu Co., Japan). The operating conditions were with a supelcosil LC-18DB column (length $25 \mathrm{~cm}$, i.d. $4.6 \mathrm{~mm}$ and particle size 5 $\mu \mathrm{m})$ (Supelco Co., USA), and a mixture of $0.01 \mathrm{M}$ phosphate buffer $\mathrm{pH} 3$ and methanol $(5: 1, \mathrm{v} / \mathrm{v})$ as the mobile phase. The flow rate was $0.8 \mathrm{~cm}^{3} \mathrm{~min}^{-1}$, and the organic acid was detected with a Shimadzu SPD-2A UV detector at wavelength $210 \mathrm{~nm}$ and integrated with a Shimadzu CR-6A recorder. Authentic organic acids were used as the standard for qualitative and quantitative determination in the range from 0.0 to $200 \mu \mathrm{M}$.

\subsection{Chemical analysis}

Moisture contents of soils were determined by drying the sample at $105^{\circ} \mathrm{C}$ overnight to a constant weight. Soil $\mathrm{pH}$ was measured in five times volume of distilled water equilibrated with soil for $1 \mathrm{~h}$ with $\mathrm{pH}$ meter (Good digital pH meter model 2002, Taiwan). Air and soil temperatures were determined directly or under $5 \mathrm{~cm}$ depth of soil with a thermometer. Experiments were carried out to obtain three measurements and statistical analysis of the results was performed using analysis of variance and Duncan's multiple range test $(p=0.05)$ with the help of the Statistical Analysis System as previously described (SAS Institute, 1988).

\section{Results}

\subsection{Soil properties}

Spruce soil of Tatachia mountain is sandy loam. The $\mathrm{pH}$ of the organic layer was the lowest, topsoil was the next, and subsoil was the highest, due to the deposition of organic layer on the surface and the incomplete decomposition of organic matter (Table 1). Spruce soil belonged to the acidic type. Moisture content of the organic layer was the highest, while subsoil was the lowest because of the lack of water penetration into soil and the effect of precipitation. Total organic carbon and nitrogen contents of the organic layer were also the highest.

\subsection{Environmental conditions}

Tatachia mountain is located in the central part of Taiwan, Nantou County. Daily air mean temperature was in the range of $4.0-17.5^{\circ} \mathrm{C}$. Air temperatures were higher than those of soil temperatures in the summer season, while the phenomenon was reversed in the winter season. The fluctuation of soil temperature was narrower than that of air temperature due to the high 
heat capacity of soil. Annual average air temperature is around $12{ }^{\circ} \mathrm{C}$, most months having cool weather. January and February have low temperature $\left(2.2-7.8^{\circ} \mathrm{C}\right)$, while August and September have high temperature (12$\left.17^{\circ} \mathrm{C}\right)$. The annual precipitation of Tatachia mountain was between 2800 and $3000 \mathrm{~mm}$, and the annual evaporation ranged from 289.4 to $432.5 \mathrm{~mm}$. The percentage of evaporation was between 9.35 and 23.9.

\subsection{Bacterial population}

Bacterial populations of Spruce soil ranged from $1.38 \pm 0.26 \times 10^{6}$ to $6.37 \pm 0.21 \times 10^{6} \mathrm{CFU} \mathrm{g}^{-1}$ dry topsoil, and from $8.07 \pm 0.55 \times 10^{5}$ to $4.70 \pm 0.96 \times 10^{6} \mathrm{CFU}$ $\mathrm{g}^{-1}$ dry subsoil (Fig. 1). Topsoil sample had higher population than that of subsoil because of the higher organic matter contents and higher oxygen concentration in the topsoil. From the statistical analysis, bacterial populations between topsoil and subsoil samples differed by $63.6 \%$.

\subsection{Actinomycetes population}

Actinomycetes are known to have a diverse set of enzymes to degrade complex compounds for energy and biomass production. Actinomycete populations were between $1.12 \pm 0.21 \times 10^{4}$ and $7.33 \pm 0.64 \times 10^{4} \mathrm{CFU} \mathrm{g}^{-1}$ dry topsoil, and between $1.90 \pm 0.16 \times 10^{3}$ and $4.96 \pm$

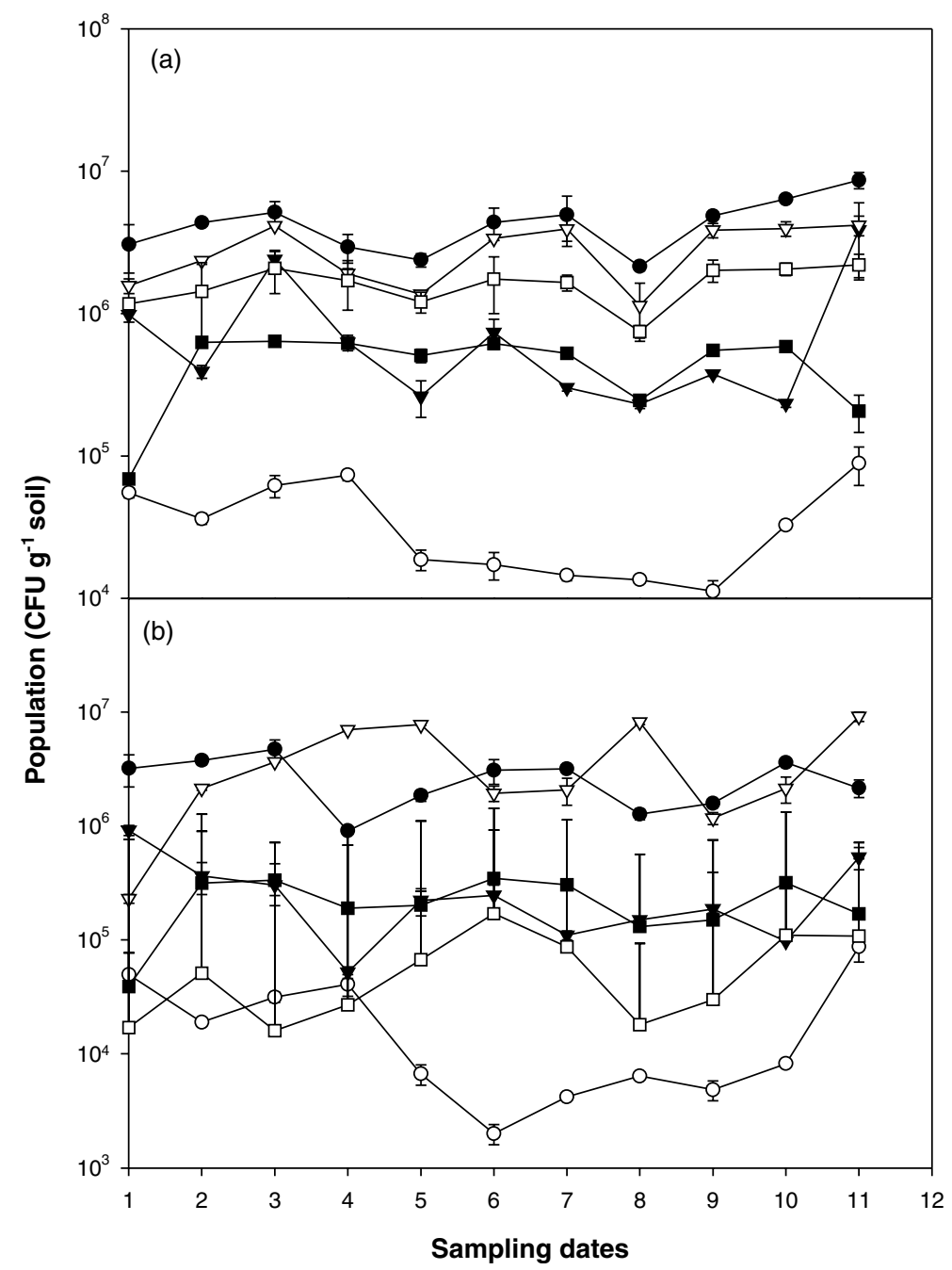

Fig. 1. Microbial population of Spruce soil in Tatachia mountain. Sampling dates were: (1) January 27, 1997; (2) April 27, 1997; (3) July 23, 1997; (4) October 10, 1997; (5) January 18, 1998; (6) April 30, 1998; (7) September 7, 1998; (8) December 11, 1998; (9) March 10, 1999; (10) April 10, 1999 and (11) November 10, 1999. (a) Topsoil (0-20 cm depth) (b) Subsoil (21-40 cm depth) (@: bacteria; $\bigcirc$ : actinomycetes; $\mathbf{\nabla}$ : fungi; $\nabla$ : cellulolytic; $\mathbf{\square}$ : phosphate-solubilizing; $\square$ : nitrogen-fixing microbes). 
$0.41 \times 10^{4} \mathrm{CFU} \mathrm{g}^{-1}$ dry subsoil (Fig. 1). Topsoil sample also had higher population than that of subsoil due to the higher organic matter content and higher oxygen concentration in the topsoil. From the statistical analysis, it was also shown that $90.9 \%$ of actinomycete populations had significant difference between tested topsoil and subsoil samples.

\subsection{Fungal population}

The $\mathrm{pH}$ of Spruce soil was acidic, which is favorable for fungal propagation. The fungal population was found to be high in the summer season as a result of warm temperature that favors fungal growth. The fungal population was high in topsoil sample due to the abundant amount of organic matter. Each gram of dry topsoil contained fungi $2.31 \pm 0.16 \times 10^{5}$ to $2.42 \pm 0.33 \times 10^{6}$ $\mathrm{CFU}$, and each gram of dry subsoil had fungi between $5.20 \pm 0.61 \times 10^{4}$ and $9.16 \pm 0.90 \times 10^{5}$ CFU (Fig. 1). From the statistical analysis of fungal population, it was found that: (1) $45.5 \%$ of topsoil samples had significant higher population than those in subsoil and (2) seasonal variation showed no significant difference.

\subsection{Cellulolytic, phosphate-solubilizing and nitrogen-fixing microbes}

Cellulolytic, phosphate-solubilizing and nitrogenfixing microbes are very important in the elemental cycle and in plant nutrition of grass and forest soils. The populations varied with the sampling season and the soil depth. Each gram of dry topsoil contained cellulolytic microbes $1.57 \pm 0.19 \times 10^{5}-4.13 \pm 0.07 \times 10^{6} \mathrm{CFU}$, while subsoil had $2.30 \pm 0.20 \times 10^{5}-3.65 \pm 0.06 \times 10^{6} \mathrm{CFU}$ (Fig. 1). About $90.9 \%$ of topsoil samples had higher cellulolytic microbes than those of subsoil. Although, the populations of cellulolytic microbes varied at different seasons, the percentage of cellulolytic microbes in the total microbial count was very consistent. The values were between $42.43 \%$ and $80.19 \%$ (average was $62.28 \%$ ), and between $41.84 \%$ and $86.37 \%$ (average was $65.19 \%$ ) in topsoil and subsoil samples, respectively. The difference between the percentage of cellulolytic microbes in the total count of topsoil and subsoil samples was not significant. The seasonal variation of microbial populations and percentage of cellulolytic microbes in the total microbial count were also not significant.

Each gram of dry topsoil had phosphate-solubilizing microbes ranging from $6.89 \pm 0.21 \times 10^{4}$ to $6.40 \pm 0.17 \times$ $10^{5} \mathrm{CFU}$, while subsoil contained $3.90 \pm 0.02 \times 10^{4}-$ $3.47 \pm 0.19 \times 10^{5}$ CFU (Fig. 1). Topsoil sample had higher number of phosphate-solubilizing microbes than subsoil in all tested samples, and $90.9 \%$ of them had significant difference. The percentage of phosphate- solubilizing microbes in the total count ranged from $9.22 \%$ to $21.30 \%$ (average was $13.37 \%$ ) in the topsoil and it ranged from $7.11 \%$ to $20.95 \%$ (average was $10.63 \%$ ) in the subsoil. The percent of phosphate-solubilizing microbes in the total microbial count were not significantly different between topsoil and subsoil samples. Seasonal variation of microbial populations also showed no significant difference between topsoil and subsoil samples.

Each gram of dry topsoil contained nitrogen-fixing microbes $7.48 \pm 0.75 \times 10^{5}-2.08 \pm 0.70 \times 10^{6} \mathrm{CFU}$, and the values were between $4.33 \pm 0.18 \times 10^{5}$ and $1.34 \pm 0.16 \times$ $10^{6} \mathrm{CFU}$ in subsoil (Fig. 1). From the statistical analysis, $54.5 \%$ of topsoil samples had significantly higher populations than those of subsoil. The percentage of nitrogenfixing microbes in the total count ranged from $31.62 \%$ to $58.89 \%$ (average was $40.49 \%$ ) and from $22.53 \%$ to $68.72 \%$ (average was $35.55 \%$ ) in tested topsoil and subsoil samples, respectively. The percent of nitrogen-fixing microbes in the total microbial count was not significantly different between topsoil and subsoil samples. Seasonal variation of the microbial populations and the percentage of nitrogen-fixing microbes were also not significant.

\subsection{Microbes in organic layer}

There is a heavy layer of organic matter on the surface of Spruce soil. Three locations, rhizosphere, nonrhizosphere and dwarf bamboo, were chosen to compare the effect of rhizosphere and microbial populations in each location are presented in Table 2. Rhizosphere soil had the highest microbial population due to the abundance of root secretion. But the difference among them was not significant. Percentage of cellulolytic, phosphate-solubilizing and nitrogen-fixing microbes in the total microbial count was lower than that of topsoil (Table 3).

\subsection{Microbial biomass carbon and nitrogen content}

Microbial biomass carbon and nitrogen contents in the organic layer, topsoil and subsoil samples are illustrated in Tables 2 and 4. Topsoil had the highest microbial biomass carbon, followed by organic layer, and subsoil was the least. In the case of microbial biomass nitrogen, topsoil had the highest, followed by subsoil, and organic layer was the least. In organic layer, rhizosphere of Spruce had the highest microbial biomass carbon and nitrogen, while non-rhizosphere area was the lowest. There were significant differences among organic layer, topsoil and subsoil; or the organic layer among rhizosphere, dwarf bamboo and non-rhizosphere areas. The seasonal variation of microbial biomass carbon and nitrogen contents in all tested samples was not significant (Table 4). 
Table 2

Properties of organic layer in Spruce soil

\begin{tabular}{|c|c|c|c|}
\hline Item & Rhizosphere of Spruce & Non-rhizosphere & Dwarf bamboo \\
\hline \multicolumn{4}{|l|}{ (a) December 11, 1998} \\
\hline $\mathrm{pH}$ & $3.58 \pm 0.10^{\mathrm{c}}$ & $4.19 \pm 0.11^{\mathrm{a}}$ & $3.88 \pm 0.12^{\mathrm{b}}$ \\
\hline Moisture content $(\%)$ & $61.03 \pm 2.71^{b}$ & $67.10 \pm 2.30^{\mathrm{a}}$ & $63.69 \pm 2.43^{\mathrm{a}, \mathrm{b}}$ \\
\hline Total carbon content $(\%)$ & $25.54 \pm 0.96^{\mathrm{a}}$ & $21.06 \pm 0.99^{\mathrm{b}}$ & $19.09 \pm 0.35^{\mathrm{b}}$ \\
\hline Total nitrogen content $(\%)$ & $2.27 \pm 0.01^{\mathrm{b}}$ & $2.51 \pm 0.03^{\mathrm{a}}$ & $2.24 \pm 0.03^{\mathrm{b}}$ \\
\hline $\mathrm{C} / \mathrm{N}$ ratio & $11.27^{\mathrm{a}}$ & $8.38^{\mathrm{b}}$ & $8.53^{\mathrm{b}}$ \\
\hline Microbial biomass $\mathrm{C}\left(\mu \mathrm{g} \mathrm{g}^{-1}\right)$ & $513.53 \pm 1.05^{\mathrm{a}}$ & $215.86 \pm 1.02^{\mathrm{c}}$ & $432.67 \pm 1.38^{\mathrm{b}}$ \\
\hline Microbial biomass $\mathrm{N}\left(\mu \mathrm{g} \mathrm{g}^{-1}\right)$ & $24.76 \pm 0.84^{\mathrm{a}}$ & $10.32 \pm 0.52^{\mathrm{b}}$ & $26.73 \pm 1.06^{\mathrm{a}}$ \\
\hline \multicolumn{4}{|l|}{ (b) March 10, 1999} \\
\hline Microbial biomass $\mathrm{C}\left(\mu \mathrm{g} \mathrm{g}^{-1}\right)$ & $624.44 \pm 1.56^{\mathrm{a}}$ & $243.33 \pm 2.89^{c}$ & $391.11 \pm 1.32^{\mathrm{b}}$ \\
\hline Microbial biomass $\mathrm{N}\left(\mu \mathrm{g} \mathrm{g}^{-1}\right)$ & $32.44 \pm 1.21^{\mathrm{a}}$ & $12.15 \pm 0.95^{\mathrm{c}}$ & $23.70 \pm 0.74^{\mathrm{b}}$ \\
\hline \multicolumn{4}{|l|}{ (c) April 10, 1999} \\
\hline $\mathrm{pH}$ & $5.00 \pm 0.07^{\mathrm{a}}$ & $4.91 \pm 0.07^{\mathrm{a}}$ & $4.82 \pm 0.02^{\mathrm{a}}$ \\
\hline Moisture content $(\%)$ & $73.70 \pm 3.51^{\mathrm{a}}$ & $63.30 \pm 4.04^{\mathrm{b}}$ & $56.70 \pm 2.08^{\mathrm{c}}$ \\
\hline Total carbon content $(\%)$ & $32.37 \pm 1.12^{\mathrm{a}}$ & $30.05 \pm 1.21^{\mathrm{a}}$ & $23.67 \pm 1.04^{\mathrm{b}}$ \\
\hline Total nitrogen content $(\%)$ & $2.19 \pm 0.05^{\mathrm{a}}$ & $2.17 \pm 0.05^{\mathrm{a}}$ & $2.10 \pm 0.04^{\mathrm{a}}$ \\
\hline $\mathrm{C} / \mathrm{N}$ ratio & $14.79^{\mathrm{a}}$ & $13.87^{\mathrm{a}}$ & $11.27^{\mathrm{b}}$ \\
\hline Microbial biomass $\mathrm{C}\left(\mu \mathrm{g} \mathrm{g}^{-1}\right)$ & $653.33 \pm 0.05^{\mathrm{a}}$ & $258.89 \pm 0.04^{\mathrm{c}}$ & $422.20 \pm 1.02^{\mathrm{b}}$ \\
\hline Microbial biomass $\mathrm{N}\left(\mu \mathrm{g} \mathrm{g}^{-1}\right)$ & $33.77 \pm 0.56^{\mathrm{a}}$ & $13.12 \pm 0.88^{\mathrm{c}}$ & $24.72 \pm 0.09^{\mathrm{b}}$ \\
\hline
\end{tabular}

Means \pm SD $(n=3)$. Means in the same row that do not share the same alphabetic superscript are significantly different at $5 \%$ levels according to Duncan's multiple range tests.

\subsection{Effect of soil depth on microbial population}

Soil property and microbial population at different horizons of Spruce soil are shown in Table 5. Soil pH increased gradually with the depth and had the highest $\mathrm{pH}$ at $2 \mathrm{~B} 2$ horizon, then decreased sharply at $1 \mathrm{E}$ horizon, whereas soil moisture content decreased with increasing depth. Microbial populations also decreased stepwise with the depth of soil. The bacterial, actinomycete and fungal counts at $2 \mathrm{~B} 2$ horizon were only $0.632 \%, 0.018 \%$ and $0.337 \%$ of those at $\mathrm{O}$ horizon, respectively.

\subsection{Organic acid content}

Organic acid content of Spruce soil is illustrated in Table 6. $\mathrm{pH}$ of organic layer in Spruce soil was the lowest, while $\mathrm{pH}$ of subsoil was the highest. $\mathrm{pH}$ value had a significant difference between organic layer and soil sample. As is expected, organic matter was higher in organic layer than that in topsoil and subsoil. Therefore, organic acid content was also high in organic layer, and low in subsoil. Each gram of dry organic layer contained formic acid $256-421 \mathrm{nM}$, acetic acid $301-435 \mathrm{nM}$, malic acid 795-1027 nM and succinic acid 204-670 nM, while subsoil had only malic acid $74-103 \mathrm{nM}$ and succinic acid 32-142 nM. Two undetermined peaks of organic acid with $3383 \pm 263$ and $1322 \pm 142$ units were also detected in organic layer.

\section{Discussion}

Tatachia mountain is located in the central part of Taiwan and the altitude is from 1800 to $3952 \mathrm{~m}$ height. It can be divided into three parts according to the vegetation, Spruce (P. morrisonicola), Hemlock (T. chinensis) and grassland. Dwarf bamboo (Y. niitakayamensis) and graminaceous ferr are also grown in this area. There is much leaf deposit on the surface of Spruce soil. $\mathrm{pH}$ of Spruce soil and organic layer were weakly acidic due to the abundant leaf litter on the surface, the incomplete decomposition of the litter and the accumulation of organic acids. Subsoil samples had higher $\mathrm{pH}$ values than those of organic layer or topsoil because of the lower organic matter and oxygen contents, and lower microbial activity and organic acid accumulation. Berg et al. (1998) indicated that Wekerom forest soil in the Netherlands had a soil pH of 3.8 due to the high organic matter content. Yang and Yang (2001) also reported that nuclear and thermal power plants in northern Taiwan had soil $\mathrm{pH}$ ranging from 4.34 to 4.47 because of the organic matter covering the surface and the inceptisol.

Soil moisture content depends on the environmental conditions and soil texture. Seasonal variation of moisture content of organic layer sample was higher than that of topsoil and subsoil due to the larger environmental change and the heavier organic matter covering. The same phenomena were also found in the power plant areas in Taiwan (Yang and Yang, 2001). In 
Table 3

Microbial populations in organic layer of Spruce soil

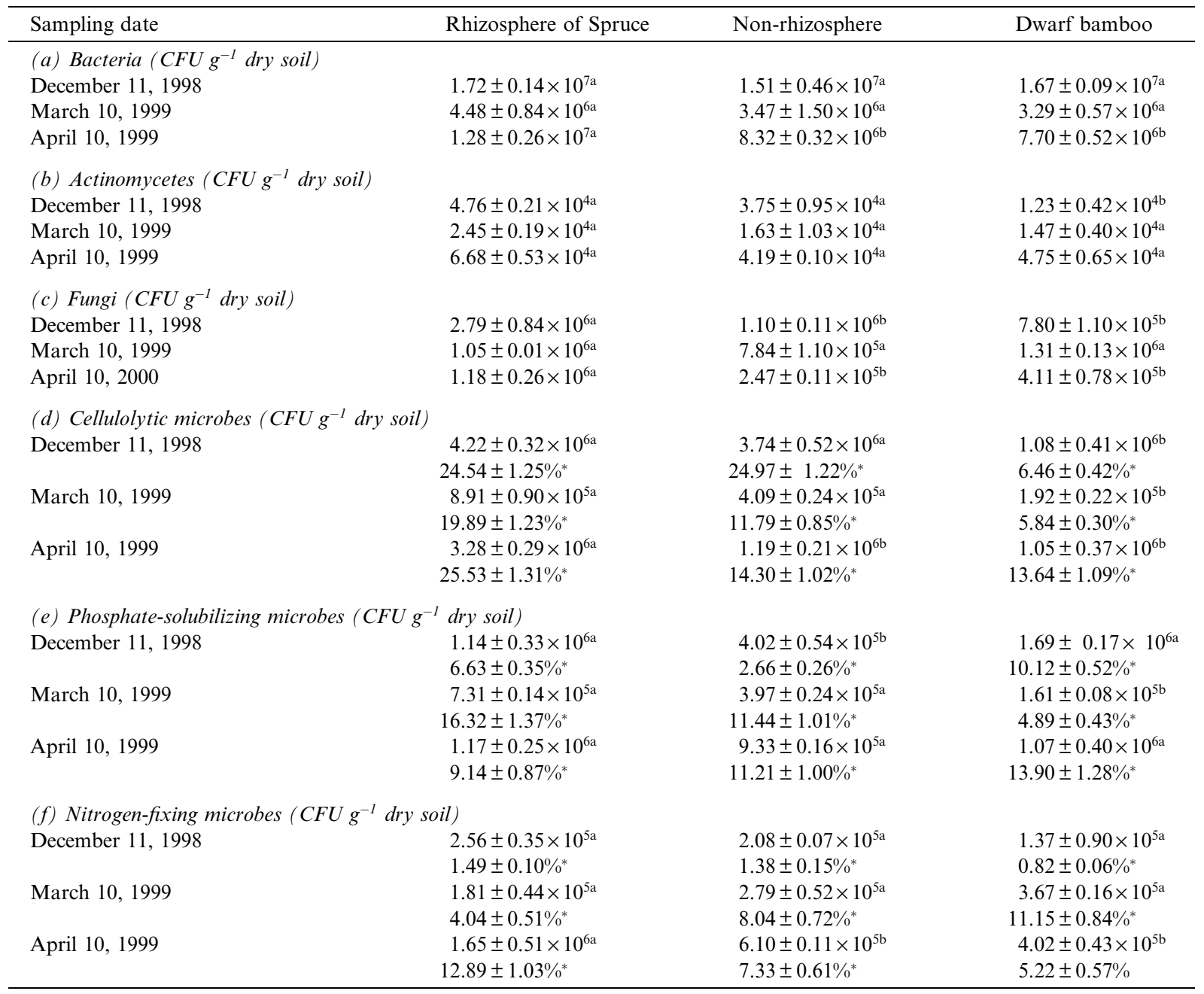

${ }^{*}$ Percent of tested microbes in total viable count. Means \pm SD $(n=3)$. Means in the same row that do not share the same alphabetic superscript are significantly different at $5 \%$ levels according to Duncan's multiple range tests.

Table 4

Microbial biomass carbon and nitrogen contents in Spruce soil

\begin{tabular}{|c|c|c|c|c|}
\hline \multirow[t]{2}{*}{ Sampling date } & \multicolumn{2}{|l|}{ Topsoil } & \multicolumn{2}{|l|}{ Subsoil } \\
\hline & $\begin{array}{l}\text { Biomass C } \\
\left(\mu \mathrm{g} \mathrm{g}^{-1} \text { dry soil }\right)\end{array}$ & $\begin{array}{l}\text { Biomass } \mathrm{N} \\
\left(\mu \mathrm{g} \mathrm{g}^{-1} \text { dry soil) }\right.\end{array}$ & $\begin{array}{l}\text { Biomass C } \\
\left(\mu \mathrm{gg}^{-1} \text { dry soil }\right)\end{array}$ & $\begin{array}{l}\text { Biomass } \mathrm{N} \\
\left(\mu \mathrm{g} \mathrm{g}^{-1} \text { dry soil }\right)\end{array}$ \\
\hline July 23, 1997 & $735 \pm 32$ & $172 \pm 11$ & $425 \pm 22$ & $132 \pm 9$ \\
\hline October 10, 1997 & $713 \pm 27$ & $165 \pm 12$ & $371 \pm 18$ & $125 \pm 10$ \\
\hline January 18, 1998 & $604 \pm 21$ & $128 \pm 10$ & $308 \pm 20$ & $107 \pm 11$ \\
\hline April 30, 1998 & $852 \pm 33$ & $214 \pm 15$ & $455 \pm 30$ & $156 \pm 23$ \\
\hline December 11, 1998 & $684 \pm 24$ & $153 \pm 9$ & $321 \pm 17$ & $115 \pm 8$ \\
\hline March 10, 1999 & $822 \pm 39$ & $218 \pm 29$ & $434 \pm 27$ & $131 \pm 11$ \\
\hline April 10, 1999 & $870 \pm 42$ & $240 \pm 11$ & $652 \pm 23$ & $173 \pm 10$ \\
\hline November 10, 1999 & $612 \pm 20$ & $183 \pm 13$ & $327 \pm 12$ & $122 \pm 11$ \\
\hline
\end{tabular}

Means \pm SD $(n=3)$. 
Table 5

Microbial population at different profiles of Spruce soil

\begin{tabular}{lllllll}
\hline Profile & $\begin{array}{l}\text { Depth } \\
(\mathrm{cm})\end{array}$ & $\mathrm{pH}$ & $\begin{array}{l}\text { Moisture } \\
\text { content }(\%)\end{array}$ & $\begin{array}{l}\text { Bacteria (CFU g } \\
\text { dry soil) }\end{array}$ & $\begin{array}{l}\text { Fungi (CFU g } \\
\text { dry soil) }\end{array}$ & $\begin{array}{l}\text { Actinomycetes } \\
\left(\mathrm{CFU} \mathrm{g}^{-1} \text { dry soil) }\right.\end{array}$ \\
\hline O horizon & $0-13$ & $4.6 \pm 0.1$ & $65.0 \pm 2.4$ & $8.55 \pm 0.05 \times 10^{6}$ & $8.55 \pm 0.35 \times 10^{5}$ & $6.41 \pm 0.82 \times 10^{5}$ \\
1A horizon & $14-31$ & $5.3 \pm 0.1$ & $23.4 \pm 0.1$ & $8.10 \pm 0.73 \times 10^{5}$ & $3.00 \pm 1.25 \times 10^{4}$ & $7.58 \pm 0.47 \times 10^{4}$ \\
2A horizon & $32-46$ & $7.2 \pm 0.1$ & $19.2 \pm 0.8$ & $3.00 \pm 0.15 \times 10^{5}$ & $4.94 \pm 1.23 \times 10^{3}$ & $1.37 \pm 0.09 \times 10^{4}$ \\
2B horizon & $47-60$ & $7.6 \pm 0.1$ & $18.0 \pm 0.8$ & $1.92 \pm 0.32 \times 10^{5}$ & $2.27 \pm 0.39 \times 10^{2}$ & $4.87 \pm 0.21 \times 10^{3}$ \\
2B2 horizon & $61-91$ & $8.0 \pm 0.1$ & $13.8 \pm 0.1$ & $5.41 \pm 1.77 \times 10^{4}$ & $1.51 \pm 0.31 \times 10^{2}$ & $2.16 \pm 0.16 \times 10^{3}$ \\
1E horizon & $>91$ & $6.4 \pm 0.1$ & $20.4 \pm 0.6$ & $2.35 \pm 0.57 \times 10^{4}$ & $3.52 \pm 0.54 \times 10^{2}$ & $9.30 \pm 1.01 \times 10^{3}$ \\
\hline
\end{tabular}

Means $\pm \operatorname{SD}(n=3)$.

Table 6

Organic acid content of Spruce soil ( $\mathrm{nM} \mathrm{g}^{-1}$ dry soil)

\begin{tabular}{llllcc}
\hline Soil depth & Sampling date & Formic acid & Acetic acid & Malic acid & Succinic acid \\
\hline Organic layer & September 7, 1998 & $256 \pm 9$ & $309 \pm 10$ & $795 \pm 12$ & $310 \pm 12$ \\
& December 11, 1998 & $284 \pm 12$ & $301 \pm 13$ & $905 \pm 32$ & $204 \pm 13$ \\
& March 10, 1999 & $330 \pm 17$ & $350 \pm 14$ & $850 \pm 25$ & $270 \pm 10$ \\
& April 10, 1999 & $421 \pm 15$ & $435 \pm 21$ & $1027 \pm 41$ & $670 \pm 23$ \\
Topsoil & September 7, 1998 & - & - & $155 \pm 7$ & $51 \pm 3$ \\
& December 11, 1998 & - & - & $108 \pm 7$ & $106 \pm 7$ \\
& March 10, 1999 & - & - & $211 \pm 12$ & $175 \pm 9$ \\
& April 10, 1999 & - & - & $85 \pm 6$ & $168 \pm 9$ \\
Subsoil & September 7, 1998 & - & - & $74 \pm 5$ & $32 \pm 3$ \\
& December 11, 1998 & - & - & $78 \pm 6$ & $53 \pm 5$ \\
& March 10, 1999 & - & - & $103 \pm 7$ & $60 \pm 6$ \\
\end{tabular}

-: Under detection; Means \pm SD $(n=3)$.

addition, the water-holding capacity of organic layer was higher than that of topsoil and subsoil because of the high organic matter content. Srivastava and Singh (1988) also showed that the water-holding capacity of forest soil was higher than that of grassland in India.

Although the variation of culturable microbes was large during the tested periods, microbial populations were low in subsoil samples due to the low total organic carbon (23.66-34.35\% in organic layer, $11.09-24.51 \%$ in topsoil and $5.83-11.20 \%$ in subsoil) and total nitrogen contents $(1.26-3.19 \%$ in organic layer, $1.06-2.87 \%$ in topsoil and $0.90-1.90 \%$ in subsoil). Srivastava and Singh (1988) showed that tropical soils had low carbon $(0.6 \%)$ and nitrogen $(0.01 \%)$ contents due to the dry condition and less vegetation. However, Tatachia forest soil had high humidity environment and heavy vegetation on the surface. Therefore, the microbial populations of Tatachia forest soils were higher than those of tropical soils in India. The microbial populations in subsoil samples showed $24.86-91.26 \%$ of bacteria, $11.63-97.98 \%$ of actinomycetes and $12.63-93.18 \%$ of fungi, $14.65-90.64 \%$ of cellulolytic microbes, $27.22-81.64 \%$ of phosphatesolubilizing microbes and $24.86-74.55 \%$ of nitrogenfixing microbes as percentages of the values in topsoil samples. However, the percent of microbial population in subsoil samples relative to organic layer samples was less than the above data. In contrast, the microbial populations in subsoil of power plant area had only $19.20-71.62 \%$ of bacteria, $21.58-87.34 \%$ of actinomycetes and $15.41-72.92 \%$ of fungi as those in topsoil due to the stickiness of tested soils for the nutrition and moisture penetration from topsoil to subsoil (Yang and Yang, 2001). Microbial populations also decreased with increasing soil depth. 2B2 horizon had only $0.633 \%$, $0.018 \%$ and $0.337 \%$ of bacteria, actinomycetes and fungi at $\mathrm{O}$ horizon, respectively. The same result was also found in grassland of Tatachia, 2A1 horizon $(21-40 \mathrm{~cm}$ depth) had only $15-40 \%, 2.1-17.4 \%$ and $0.6-2.1 \%$ of bacteria, actinomycetes and fungi at $O$ horizon $(0-20 \mathrm{~cm}$ depth), respectively (Yang et al., 1998a). Bt horizon (39$52 \mathrm{~cm}$ depth) was only $3.32 \%$ of respiration and $1.75 \%$ of ergosterol content as Oe1 horizon (0-15 cm depth) in Hemlock soil of Tatachia (Imberger and Chiu, 2001). The humus layer of Vaccinium vitisidaea fertile site of Finland forest had higher numbers of culturable bacteria, pseudomonads, fungi and yeasts than those in the mineral soil (0-3 cm depth) (Priha et al., 2001). Microbial activity, biomass, ATP content and respiration decreased with increasing depth in beech forest soil (Stockfish et al., 1995; Lavahun et al., 1996). Bacterial 
population and mycelial content decreased with increasing depth in pine forest soil (Berg et al., 1998). Nitrifying bacterial count also decreased with increasing soil depth in acidic forest soil of Douglas (de Boer et al., 1992).

Cellulolytic, phosphate-solubilizing and nitrogenfixing microbes are very important in grassland and forest soil for the elemental cycle and the nutritional supplement. Although these populations varied with season and location, the ratios of these microbes to the total viable count could be used to assay the change of microbial ecology. The ratios of cellulolytic microbes to the total viable count were between $41.84 \%$ and $86.37 \%$ in Spruce soil, which were higher than $17.21-60.20 \%$ in nuclear and thermal power plants areas (Yang and Yang, 2001) and $11.53-25.15 \%$ in grassland of Tatachia (Yang et al., 1998a) due to the heavy coverage of organic matter lying on the surface of Spruce soil. Bradley and Fyles (1995) suggested that basal respiration was 2-3 times high in birch due to the high amount of root-labile $\mathrm{C}$ in this area. Tietema and Wessel (1994) also reported that oak leaf decomposition microbes were very active in forest soil for the elemental cycle and the nutritional supplement.

Microbial biomass carbon was high in topsoil sample and low in subsoil. The value was higher than that in tropical soils (149-667 $\mu \mathrm{g} \mathrm{Cg}^{-1}$ dry soil), due to high temperature and low organic matter content in India (Srivastava and Singh, 1988). However, it was at the same level as the tropical forest soil in India (341-872 $\mu \mathrm{g} \mathrm{C}^{-1}$ dry soil) (Raghubanshi, 1991), but lower than forest soil in Germany (317-2116 $\mu \mathrm{g} \mathrm{Cg}^{-1}$ dry soil) (Joergensen et al., 1990). In microbial biomass nitrogen, topsoil of Spruce had a value higher than that in tropical forest soil in India (38-78 $\mu \mathrm{g} \mathrm{N} \mathrm{g}^{-1}$ dry soil) (Raghubanshi, 1991), and at the same level as forest soil in Germany (30-347 $\mu \mathrm{g} \mathrm{N} \mathrm{g}^{-1}$ dry soil) (Joergensen et al., 1990). Fumigation-extraction biomass carbon of pine and spruce forest soils in Finland was also higher in 0-3 $\mathrm{cm}$ depth of mineral soil than that in $0-6 \mathrm{~cm}$ depth of mineral soil (Priha et al., 2001). Rhizosphere soil of Spruce had high microbial biomass carbon and nitrogen contents because of the abundance of root secretion. In addition, microbial populations in organic layer of Spruce rhizosphere were also higher than that of nonrhizosphere or dwarf bamboo. The differences in the chemical composition of litter and root exudates would be expected to result in differential availability of various carbon sources among stands of different tree species (Johansson, 1995; Grayston et al., 1996). Different mycorrhizal symbionts on the root of these trees can also significantly alter the chemical, physical and microbial composition of rhizosphere (Linderman, 1988).

Heavy coverage of organic matter was found in Spruce soil. Much organic acid was accumulated in the soil. Acetic acid and formic acid were only found in organic layer, while the concentration of them in soil was below detection. Acetic acid and short chain fatty acids were found in anaerobic hog waste treatment (Nyns, 1989). Acetic acid, citric acid, fumaric acid, 2ketogluconic acid, lactic acid, oxalic acid, and succinic acid were accumulated in microbially contaminated fuel oil (Yang et al., 1996), rhizosphere (Duff et al., 1963; Halder et al., 1991), and phosphate-solubilizing microbes (Gyaneshwar et al., 1998). Chen and Yang (2000) reported that $2 \mathrm{~B} 2$ horizon ( $>56 \mathrm{~cm}$ depth) of Hemlock soil had only $2.17-14.28 \%$ of organic acid at $\mathrm{O}$ horizon $(0-13 \mathrm{~cm}$ depth $)$ in Tatachia.

\section{Conclusion}

In conclusion, Tatachia soil was weakly acidic. Bacteria were most abundant, followed by cellulolytic microbes, phosphate-solubilizing microbes, nitrogen-fixing microbes, fungi, and actinomycetes. Total organic carbon and nitrogen contents were high in Spruce soil of Tatachia. The microbial populations, microbial biomass carbon and nitrogen contents were also high in topsoil samples and low in subsoil. Microbial populations were significantly different between topsoil and subsoil samples. The ratios of cellulolytic microbes to the total viable count were high due to the heavy coverage of organic matter lying on the soil surface. Malic acid and succinic acid were the major organic acid in soil, while acetic acid and formic acid were also found in organic layer. They had positive correlation between microbial populations and microbial biomass carbon, between microbial populations and organic acid content.

\section{Acknowledgements}

The authors thank Ms. Lung-Yueh Sun, Ms. ChiaBei Wei and Dr. Ed-Hong Chang for their technical assistance, and National Science Council of Republic of China for financial support (NSC86-2621-B002-021A07, NSC87-2621-B002-020-A07 and NSC88-2621B002-017-A10).

\section{References}

Alexander, M., 1977. Introduction to Soil Microbiology, second ed. John Wiley \& Sons, New York, pp. 16-72.

Atlas, R.M., Bartha, R., 1998. Microbial Ecology. Fundamentals and Applications, fourth ed. Benjamin/Cummings Science Publishing, New York, pp. 174-217.

Berg, M.P., Kniese, J.P., Verhoef, H.A., 1998. Dynamic and stratification of bacteria and fungi in the organic layers of a Scots pine forest soil. Biology and Fertility of Soils 26, 313322.

Bradley, R.L., Fyles, J.W., 1995. Growth of paper birch (Betula papyrifera) seedings increases soil available $\mathrm{C}$ and microbial 
acquisition of soil nutrients. Soil Biology and Biochemistry 27, 1565-1571.

Chen, W.S., Yang, S.S., 2000. Organic acid contents in Tatachia forest soils. Journal of the Experimental Forestry, National Taiwan University 14, 99-108.

Chu, L.R., 1933. Properties of microbes in irrigation land. General concept and inoculum of Rhizobium. Journal of Tropic Agriculture 5, 107-121.

de Boer, W., Tietema, A., Gunnewick, P.J.A.K., Laanbroek, H.J., 1992. The chemolithotrophic ammonium-oxidizing community in a nitrogen-saturated acid forest soil in relation to $\mathrm{pH}$-dependent nitrifying activity. Soil Biology and Biochemistry 24, 229-234.

Duff, R.B., Webley, D.M., Scott, R.O., 1963. Solubilization of minerals and related materials by 2-ketogluconic acid producing bacteria. Soil Science 95, 105-114.

Grayston, S.J., Vaughan, D., Jones, D., 1996. Rhizosphere carbon flow in trees, in comparison with annual plants: the importance of root exudation and its impact on microbial activity and nutrient availability. Applied Soil Ecology 5, 29-56.

Gyaneshwar, P., Kumar, G.N., Parekh, L.J., 1998. Effect of buffering on the phosphate-solubilizing ability of microorganism. World Journal of Microbiology and Biotechnology 14, 669-673.

Halder, A.K., Mishra, A.K., Chakrabartty, P.K., 1991. Solubilizing of inorganic phosphate by Badyrhizobium. Indian Journal of the Experimental Biology 29, 28-31.

Imberger, K.T., Chiu, C.Y., 2001. Spatial changes of soil fungal and bacterial biomass from a sub-alpine coniferous forest to grassland in a humid, sub-tropical region. Biology and Fertility of Soils 33, 105-110.

Joergensen, R.G., Brooks, P.C., Jenkinson, D.S., 1990. Survival of the soil biomass at elevated temperatures. Soil Biology and Biochemistry 22, 1129-1139.

Johansson, M.B., 1995. The chemical composition of needle and leaf litter from Scots pine, Norway spruce and white birch in Scandinavian forests. Forestry 68, 49-62.

Lavahun, M.F.E., Joergensen, R.G., Meyer, B., 1996. Activity and biomass of soil microorganisms at different depths. Biology and Fertility of Soils 23, 38-42.

Linderman, R.G., 1988. Mycorrhizal interactions with the rhizosphere microflora: the mycorrhizosphere effect. Phytopathology 78, 366-371.

Nelson, D.W., Sommers, L.E., 1982. Total carbon, organic carbon and organic matter. In: Page, A.L. (Ed.), Methods of Soil Analysis: Part 2. Chemical and Microbiological Properties, second ed. American Society of Agronomy, Madison, Wisconsin, pp. 539-580.
Nyns, E.J., 1989. Methane fermentation. In: Kitani, O., Hall, C.W. (Eds.), Biomass Handbook. Gordon and Breach Science Publishers, New York, pp. 287-301.

Priha, O., Grayston, S.J., Hiukka, R., Pennanen, T., Smolander, A., 2001. Microbial community structure and characteristics of the organic matter in soils under Pinus sylvestris, Picea abies and Betula pendula at two forest sites. Biology and Fertility of Soils 33, 17-24.

Raghubanshi, A.S., 1991. Dynamics of soil biomass C, N, and $\mathrm{P}$ in a dry tropical forest in India. Biology and Fertility of Soils 12, 55-59.

SAS Institute, 1988. SAS/STAT User's Guide, Release 6.03. SAS Institute, Cary, NC.

Srivastava, S.C., Singh, J.S., 1988. Carbon and phosphorus in the soil biomass of some tropical soils of India. Soil Biology and Biochemistry 20, 743-747.

Stockfish, N., Joergensen, R.G., Wolters, V., Klein, T., Eberhardt, U., 1995. Examination of microbial biomass in beech forest moder profiles. Biology and Fertility of Soils 19, 209-214.

Tietema, A., Wessel, W.W., 1994. Microbial activity and leaching during initial oak leaf linear decomposition. Biology and Fertility of Soils 18, 49-54.

Vance, E.D., Brookes, P.C., Jenkinson, D.S., 1987. An extraction method for measuring soil microbial C. Soil Biology and Biochemistry 19, 703-707.

Yang, C.K., Yang, S.S., 2001. Microbial ecology of soils surrounding nuclear and thermal power plants in Taiwan. Environment International 26, 315-322.

Yang, S.S., Chang, H.L., Wei, C.B., Lin, H.C., 1991. Reduce waste production with modified Kjeldahl method for nitrogen measurement. Journal of the Biomass Energy Society of China 10, 147-155.

Yang, S.S., Chen, C.Y., Wei, C.B., Lin, Y.T., 1996. Microbial corrosion of aluminum alloy. Chinese Journal of Microbiology and Immunology 29, 185-196.

Yang, S.S., Lai, C.M., Sun, L.Y., Luo, Y.C., Fan, H.Y., Yang, C.K., Wei, C.B., 1998a. Microbial ecology of Tatachia mountain soil. Journal of Chinese Agricultural Chemical Society 36, 229-238.

Yang, S.S., Sun, R.Y., Yang, C.K., Wei, C.B., Huang, R.Y., Hsu, W.F., 1998b. Microbial population at nuclear power plant No. 2 and its surrounding areas. Journal of Environmental Protection Society of ROC 21, 144-158.

Yang, S.S., Lin, Y.C., Yang, C.K., Chang, E.H., Wei, C.B., 1999. Microbial ecology of Hsieh-Ho thermal power plant and its surrounding area. Journal of Microbiology, Immunology and Infection 32, 269-277. 